\title{
BEBERAPA SIFAT FISIK DAN KIMIA TANAH GAMBUT TERBAKAR DAN TIDAK TERBAKAR DI DESA SUNGAI BESAR KABUPATEN KETAPANG
}

\author{
(Some Physical and Chemical Properties of Burned Peatland Soil Burned and Unburned \\ Peatland Soil in Sungai Besar Vilage of Ketapang District)
}

\author{
Mintari, Dwi Astiani, Togar Fernando Manurung. \\ Fakultas Kehutanan Universitas Tanjungpura Jl. Daya Nasional Pontianak 78124 \\ Email: mintari2302@gmail.com
}

\begin{abstract}
Peatlands is one of the ecosystem types in tropical rainforests. Peatland has very high conservation value and other functions such as the hydrological function carbon stocks, and biodiversity which is important for environmental comfort and animal life. The purpose of this study was to obtain information about the impact of fires on the physical and chemical properties of burning and non burning peat soils. This study carried out a field survey method with deliberate sampling (purposive sampling). The results showed that the physical and chemical properties of peat soil after a fire did not change, namely at soil temperature, air humidity was almost the same while the air temperature, soil moisture, $\mathrm{pH}$, C-organic, depth, $C / N(0-20 \mathrm{~cm})$ has increased but not significantly. For the chemical properties of peat soil after fire there is an increase in the value of $C$-organic, CEC, phosphorus, sulfur,ash content, $N$-total depth $(21-40 \mathrm{~cm})$. this means that after fires the nutrients mostly affect peat soil. From the information on the nature of peat soil obtained in land restoration studies to use qualitative soil after burning.
\end{abstract}

Keywords: Burn, chemical pea soil, Peatlands, Physicalpeat soil.

\section{PENDAHULUAN}

Kalimantan Barat memiliki hutan rawa gambut seluas 1,73 juta ha (Wahyunto dkk, 2005) dan hutan ini memiliki kekayaan alam berupa pohon dengan keanekaragaman jenis tumbuhan yang relatif tinggi. Lahan gambut di Kalimantan Barat secara umum telah merupakan hutan rawa sekunder atau bekas tebangan yaitu seluas $1.582 .922 \mathrm{Ha}$ dan salah satunya terdapat di Desa Sungai Besar Kabupaten Ketapang. Kawasan hutan rawa gambut Desa Sungai Pelang, Sungai Besar, dan Pematang gadung mencapai kedalaman 12 meter.

Lahan gambut (peatlands) merupakan salah satu tipe ekosistem di hutan hujan tropis, lahan gambut mempunyai nilai konservasi sangat tinggi dan fungsi-fungsi lainnya seperti fungsi hidrologi cadangan karbon, dan biodiversitas yang penting untuk kenyamanan lingkungan dan kehidupan satwa.Hutan rawa gambut sebagai ekosistem hutan tropis merupakan salah satu ekosistem yang paling rawan terhadap bahaya kebakaran, kontribusi terhadap dampak kebakaran hutan rawa gambut sangat besar karena tingginya kandungan karbon dan besarnya jumlah karbon yang dilepaskan pada saat terjadi kebakaran.

Sifat fisik tanah gambut sangat penting diperhatikan terutama dengan pengelolaan air tanahnya. Pertumbuhan 
tanaman dipengaruhi oleh sifat-sifat kesuburan tanahnya yakni kesuburan fisik, kesuburan kimia, dan kesuburan biologis. Kesuburan fisik lebih mengutamakan tentang keadaan fisik tanah yang banyak kaitannya dengan penyediaan air dan udara tanah, dan kesuburan kimia yang menyangkut dalam masalah-masalah ketersediaan unsur hara bagian pertumbuhan tanaman (Fauzi, 2008).

Dampak kebakaran lahan, termasuk pada lahan gambut, bisa berpengaruh pada dua sisi yaitu dampak on site (pada lahannya) dan dampak off site (di luar sistem lahannya). Dampak on site meliputi peningkatan $\mathrm{pH}$ tanah, peningkatan garam-garam mudah larut (basa-basa tukar), yang mendorong peningkatan kejenuhan basa (Rauf dan Fauzi, 2013). Kebakaran di lahan gambut merupakan cerminan dari sistem pengelolaan hutan atau lahan yang mengabaikan sifat-sifat dan watak lahan dan lingkungan gambut yaitu mudah kering dan terbakar.

\section{METODE PENELITIAN}

Penelitian ini dilakukan dengan metode survey lapangan yaitu dengan pengambilan contoh tanah gambut secara (purposive sampling) atau sengaja. Sampel diambil dilokasi penelitian dengan kedalaman tanah 0-20 cm, 21-40 cm diambil sampel tanah 5 titik dengan 2 sampel dimasing-masing lokasi lahan gambut terbakar dan lahan gambut yang tidak terbakar berjumlah 20 sampel.

Data yang diambil dari penelitian ini yaitu: suhu tanah, kelembaban tanah, suhu udara, kelembaban udara, $\mathrm{pH}$, C-organik, KTK, N-Total, fosfor, belerang, kadar abu, $\mathrm{C} / \mathrm{N}$.

\section{HASIL DAN PEMBAHASAN}

Sifat Fisik Tanah Gambut $(0-20 \mathrm{~cm})$

Data yang diambil di lapangan hanya di kedalaman 0-20 cm karena alat yang digunakan tidak memadahi (panjang alat hanya $20 \mathrm{~cm}$ ). Hasil penelitian yang didapat setelah menganalisis beberapa sifat-sifat fisik tanah gambut dapat dilihat secara lengkap di Table 1.

Tabel 1. Sifat fisik tanah gambut 0-20 cm (Physical characteristics of peat soils 0-20

\begin{tabular}{ccc}
$c$ & \\
\hline Pm) & \multicolumn{2}{c}{ Sifat Fisik } \\
\cline { 2 - 3 } Parameter & Terbakar & Tidak Terbakar \\
\hline Suhu Tanah & $29^{\circ} \mathrm{C}-32^{\circ} \mathrm{C}$ & $29^{\circ} \mathrm{C}-31^{\circ} \mathrm{C}$ \\
Kelembaban Tanah & $67,06 \%$ & $82,84 \%$ \\
Suhu Udara & $62,76^{\circ} \mathrm{C}$ & $68,42^{\circ} \mathrm{C}$ \\
Kelembaban Udara & $77,88 \%$ & $80,06 \%$ \\
\hline
\end{tabular}

Suhu tanah merupakan faktor penting dalam menentukan proses-proses fisika yang terjadi di dalam tanah antara lain proses-proses pelapukan bahan organik di tanah gambut. Dari hasil penelitian yang di dapat di lapangan yaitu $29^{\circ} \mathrm{C}-32^{\circ} \mathrm{C}$ di lokasi terbakar sedangkan di lokasi tidak terbakar yaitu $29^{\circ} \mathrm{C}-31^{\circ} \mathrm{C}$ ini menunjukan bahwa suhu tanah di lokasi terbakar cenderung lebih tinggi dari pada lokasi tidak terbakar. Kondisi tingginya temperatur dapat disebabkan perbedaan dilokasi terbakar lebih terbuka karena vegetasi yang banyak terbakar dan warna 
tanah bekas terbakar yang lebih gelap membuat penyerapan radiasi secara langsung ke permukaan tanah, sedangkan di lokasi tidak terbakar lebih tertutup oleh vegetasi sehingga dapat mengurangi radiasi yang di terima oleh tanah.

Kelembaban tanah adalah air yang mengisi sebagian atau seluruh pori-pori tanah yang berada di atas water table (Jamulya dan Suratman, 1993). Kelembaban tanah pada suatu lokasi dipengaruhi oleh besarnya tingkat kadar air di dalam tanah. Kelemban tanah merupakan salah satu faktor yang dapat digunakan sebagai indikator tingkat kekeringan suatu areal. Secara umum jika semakin tinggi kelembaban suatu lahan semakin kecil peluang terjadinya kekeringan parameter lahan tersebut. Pengukuran kelembaban tanah dilakukan langsung di lapangan, dari hasil yang di dapat setiap TMA menunjukan variasi nilai kelembaban tanah dilokasi terbakar reratanya $67,06 \%$ sedangkan di lokasi tidak terbakar reratanya $82,84 \%$.

Suhu udara di permukaan bumi adalah relatif, tergantung pada faktorfaktor yang mempengaruhinya seperti lamanya penyinaran matahari, vegetasi yang secara langsung menutupi penyinaran matahari, awan yang tebal dan hujan. Pengukuran suhu udara dilakukan langsung di lapangan dari hasil pengukuran yang didapat di lokasi terbakar yaitu $62,76^{\circ} \mathrm{C}$, sedangkan di lokasi tidak terbakar yaitu $68,42^{\circ} \mathrm{C}$.

Kelembaban udara adalah banyaknya uap air yang terkandung dalam udara atau atmosfer. Besarnya tergantung dari masuknya uap air ke dalam atmosfer karena adanya penguapan dari tumbuhtumbuhan, sedangkan banyaknya air didalam udara tergantung banyak faktor antara lain ketersediaan air, sumber uap, suhu uadara, tekanan udara, dan angin. Kelembaban udara yang cukup besar memberikan petunjuk langsung bahwa udara banyak mengandung uap air atau udara dalam keadaan basah. Pengukuran kelembaban udara dilakukan langsung di lapangan, dari hasil yang didapat menunjukan variasi nilai kelembaban udara di lokasi terbakar yaitu 77,88\% sedangkan di lokasi tidak terbakar yaitu $80,06 \%$.

Sifat Kimia Tanah Gambut Kedalaman 0-20 cm dan 21-40 cm Terbakar dan Tidak Terbakar

Data yang diambil di lapangan di kedalaman 0-20 cm dan 21-40 cm. Data tentang sifat kimia tanah gambut dapat dilihat secara lengkap di Table 2. 
Vol. 7 (2) : 947 - 955

Tabel 2. Sifat kimia tanah gambut $0-20 \mathrm{~cm}$ dan $21-40 \mathrm{~cm}$ (Chemical properties of peat soils 0-20 cm and $21-40 \mathrm{~cm}$ )

\begin{tabular}{ccccc}
\hline \multirow{2}{*}{ Parameter } & \multicolumn{3}{c}{ Sifat Fisik } \\
\cline { 2 - 5 } & \multicolumn{2}{c}{$0-20 \mathrm{~cm}$} & \multicolumn{2}{c}{$21-40 \mathrm{~cm}$} \\
& Terbakar Tidak Terbakar & Terbakar Tidak Terbakar \\
\hline pH & 3,682 & 3,556 & 3,402 & 3,556 \\
C-organik & 44,714 & 53,404 & 43,648 & 53,448 \\
Kapasitas Tukar Kation & 95,128 & 113,61 & 92,86 & 113,71 \\
Nitrogen Total & 1,746 & 1,892 & 1,752 & 53,448 \\
Fosfor & 480,442 & 225,408 & 315,264 & 449,448 \\
Belerang & 81,378 & 74,58 & 101,222 & 116,642 \\
Kadar Abu & 22,906 & 7,928 & 24,742 & 7,844 \\
C/N & 24,67 & 28,226 & 24,22 & 28,218 \\
\hline
\end{tabular}

Pembahasan tentang sifat kimia tanah gambut terbakar dan tidak terbakar kedalaman 0-20 cm dan 21-40 cm:

1. $\mathrm{pH}$ kedalaman $0-20 \mathrm{~cm}$

Reaksi tanah (pH tanah) menunjukan sifat kemasaman dan alkalinitas tanah yang dinyatakan dengan nilai $\mathrm{pH}$. Nilai $\mathrm{pH}$ menunjukan konsentrasi ion hydrogen $(\mathrm{H})$ dalam tanah, semakin banyak $\mathrm{H}$ dalam tanah maka semakin masam tanah tersebut. Tanah gambut mempunyai nilai $\mathrm{pH}$ yang rendah yang bekisar antara 3-5. Hasil analisis sampel tanah dilakukan di laboratorium menunjukan bahwa kandungan $\mathrm{pH}<4,0$ tergolong sedang (Andriesse, 1974). Dengan kisaran antara 3,19-4,03 tergolong masam, ini menunjukan bahwa $\mathrm{pH}$ di lokasi terbakar sedikit lebih tinggi daripada lokasi tidak terbakar, tanah bekas terbakar dapat meningkatkan $\mathrm{pH}$ tanah jika suhu di tanah tinggi ketika terjadi kebakaran.

Tingkat kemasaman tanah gambut mempunyai kisaran sangat lebar. Umumnya tanah gambut tropik, terutama gambut ombrogen (oligotrofik) mempunyai kisaran $\mathrm{pH}$
3,0-4,5 kecuali yang mendapatkan pengaruh penyusupan air laut atau payau. Kemasaman tanah cenderung makin tinggi jika gambut tersebut makin tebal (Noor, 2001). Hasil analisis sampel tanah dilakukan di laboratorium menunjukan bahwa kandungan $\mathrm{pH}$ dengan kisaran 3,25-4,01 tergolong sedang, kebakaran lahan dapat meningkatkan kondisi $\mathrm{pH}$ di kedalaman $21-40 \mathrm{~cm}$.

2. C-organik kedalaman 0-20 cm

C-organik merupakan indikator dalam penentuan bahan organik yang sangat berkaitan dengan laju dekomposisi tanah. Menurut Agus et al (2011) tingkat kematangan gambut dapat menunjukan bahwa jika tingkat dekomposisi tinggi maka akan semakin kecil cadangan karbon yang terdapat di dalam tanah tersebut. Hasil analisis sampel tanah di laboratorium menunjukan bahwa kandungan $\mathrm{C}$ organik tanah seluruhnya lebih dari 5\% tergolong sangat tinggi, dengan kisaran $14,63-54,33 \%$.

Menurut Hakim

(2003) menjelaskan bahwa dengan pemberian bahan organik dapat meningkat 
kandungan C-organik tanah dan juga dapat mempengaruhi sifat tanah menjadi lebih baik secara fisik, kimia, dan biologi. Karbon merupakan sumber makanan mikroorganisme tanah, sehingga keberadaan C-organik dalam tanah akan memacu kegiatan mikroorganisme sehingga meningkatkan proses dekomposisi tanah dan juga reaksi-reaksi yang memerlukan bantuan mikroorganisme misalnya pelarutan P dan fiksasi N. Hasil analisis sampel tanah dilakukan di laboratorium menunjukan bahwa kandungan Corganik dengan kisaran 16,21-54,76 tergolong tinggi. Pada kawasan tidak terbakar penurunan ketersediaan bahan C-organik ini tergantung pada intensitas api, jumlah bahan organik dan sifat $\mathrm{C}$ organik ketika terjadi kebakaran. Semakin tingginya intensitas api yang terjadi yaitu suhu kebakaran yang tinggi dan semakin banyak jumlah bahan Corganik yang terbakar serta mudahnya sifat bahan C-organik yang terbakar maka mempercepat penuruan jumlah bahan C-organik di tanah.

3. Kapasitas Kukar Kation kedalaman $0-20 \mathrm{~cm}$

Kapasitas tukar kation merupakan kemampuan tanah dalam menyerap dan melepaskan kation yang dinyatakan sebagai total kation yang dapat dipertukarkan. Nilai KTK tanah gambut sangat beragam tergantung pada tingkat dekomposisinya. Hasil analisis sampel tanah di lakukan di laboratorium menunjukan bahwa kandungan KTK tergolong sangat tinggi yaitu 104,74$115,58 \%$, hal ini disebabkan karena perubahan KTK tergantung pada itensitas kebakaran yang terjadi, tekstur tanah dan persediaan bahan organik di tanah (Mukhlis, 2011).

Kapasitas tukar kation (KTK) pada tanah gambut lebih besar dibandingkan tanah mineral, KTK tanah gambut berkisar dari $<50-100 \mathrm{cmol}(+) \mathrm{kg}^{1}{ }^{1}$ bila dinyatakan atas dasar volume (Noor,2001). KTK gambut terutama ditentukan oleh fraksi lignin dan subtansi humat yang relatif stabil, termasuk asam-asam humat dan relative yang bersifat hidrofilik dan agresif yang biasanya membentuk kompleks stabil dengan ion-ion logam. Hasil analisis sampel tanah di laboratorium menunjukan bahwa kandungan KTK dengan kisaran 105,8-106,93 tergolong sangat tinggi, kebakaran dapat meningkatkan kondisi KTK di kedalaman 21-40 cm.

4. Nitrogen Total kedalaman 0-20 cm

Unsur hara nitrogen memiliki peran yang sangat berpengaruh terhadap pertumbuhan tanaman, artinya nitrogen merupakan sifat kimia tanah yang sangat dibutuhkan. Hasil analisis tanah dilakukan di laboratorium menunjukan bahwa kandungan nitrogen total dengan kisaran 1,9-1,92 tergolong tinggi. Kandungan nitrogen total tertinggi umumnya terdapat pada lapisan 0-20 $\mathrm{cm}$ dan 21-40 cm, dimana perakaran dan mikroorganisme cukup itensif di lokasi tersebut. Menurut Andriesse (1988) dengan meningkatnya umur dan pembukaan lahan gambut, kandungan nitrogen total akan meningkat dan berkorasi dengan tingkat dekomposisi. 
Nitrogen merupakan hara yang paling banyak mendapat perhatian, karena jumlah nitrogen yang terdapat di dalam tanah sedikit sedangkan yang di angkut tanaman berupa panen setiap musim cukup banyak. Menurut Hakim et al, 1986 nitrogen masuk ke dalam tanah akibat dari kegiatan renik, baik yang hidup bebas maupun yang bersimbiosis dengan tanaman. Hasil analisis sampel dilakukan di laboratorium menunjukan bahwa kandungan nitrogen total dengan kisaran 1,37-54,76 tergolong tinggi, kebakaran dapat meningkatkan kondisi nitrogen total di kedalaman 21-40 cm.

5. Fosfor kedalaman $0-20 \mathrm{~cm}$

Fosfor merupakan salah satu sifat kimia penting di dalam tanah gambut, baik jika akan difungsikan sebagai lahan pertanian dan lainnya. Jika nilai $\mathrm{P}$ tinggi biasanya tanah akan semakin subur. Hasil analisis sampel tanah dilakukan di laboratorium menunjukan bahwa kandungan fosfor dengan kisaran 102,99-881,16 tergolong tinggi. Hal ini disebabkan terganggunya proses dekomposisi bahan fosfor (mineralisasi) menjadi anorganik karena banyaknya jasad mikro yang mati akibat kebakaran yang terjadi pada lahan gambut (Brady, 1974).

Fosfor dalam tanah tidak semua dapat segera tersedia, hal ini tergantung pada sifat dan ciri tanah serta pengelolahan tanah. Fosfor bersumber dari deposit bsntusn dan mineral yang mengandung fosfor didalam kerak bumi yang diduga kurang lebih $0,21 \%$ fosfor. Fosfor tersedia didalam tanah dapat diartikan sebagai $\mathrm{P}$ tanah yang dapat diekstrasikan oleh air dan asam nitrat. Sedangkan kehilangan $\mathrm{P}$ dapat terjadi karena terangkut, tercuci dan tererosi. Hasil analisis sampel tanah dilakukan di laboratorium menunjukan bahwa kandungan fosfor dengan kisaran 86,79994,54 tergolong tinggi, kebakaran lahan dapat meningkatkan kondisi fosfor di kedalaman $21-40 \mathrm{~cm}$.

6. Belerang kedalaman 0-20 cm

Belerang adalah bagian yang penting dari protein dan asam amino, umumnya belerang merupakan sumber utama belerang untuk pertumbuhan tanaman. Bahan organik tanah dikenal sebagai penyumbang utama sulfur yang dapat tersedia bagi tanaman, menurunkan kandungan bahan organik sering dianggap sebagai suatu waktu yang menyumbang terhadap berkurangnya belerang (Goenandi, 2006). Hasil analisis sampel tanah dilakukan di laboratorium menunjukan bahwa kandungan belerang dengan kisaran 48,96-115,68.

Belerang atau sulfur adalah unsur kimia dalam table periodik yang memiliki lambing $\mathrm{S}$ dan nomor atom 16. Bentuknya adalah non-metal yang tak berasa, tak berbau dan multivalent. Belerang dalam bentuk aslinya, adalah sebuah zat padat kristalin kuning. Pada mulanya unsure ini disebut brimsone yang berarti batu yang mudah terbakar. Belerang juga terdapat dalam gas alam, minyak bumi, dan batu bara. Dalam keadaan bebas, umumnya terdapat di daerah gunung berapi (Nugroho, 2009). Hasil analisis sampel tanah dilakukan di 
laboratorium menunjukan bahwa kandungan belerang dengan kisaran 57,4-208,61, kebakaran lahan dapat meningkatkan kondisi belerang di kedalaman 21-40 cm.

7. Kadar Abu kedalaman 0-20 cm

Kadar abu pada tanah gambut merupakan salah satu tahapan penguji untuk mendapatkan nilai dari kadar organik suatu tanah. Kadar abu pada tanah gambut dapat dijadikan sebagai salah satu penguji untuk menentukan tingkat kematangan suatu gambut. Tingkat kadar abu mempunyai hubungan dengan tingkat kematangan gambut (Setiawan, 1991). Hasil analisis sampel tanah dilakukan di laboratorium menunjukan bahwa kandungan kadar abu dengan kisaran 6,33-15,11, peningkatan kadar abu tanah berhubungan dengan proses dekomposisi bahan organik tanah karena kadar abu pada lapisan atas lahan yang terdrainase berasal dari berkurangnya bahan organik karena proses dekomposisi selain itu disebabkan karena kebakaran lahan yang diikuti oleh peningkatan akumulasi abu (Usuga et al, 2010).

Kadar abu pada tanah gambut merupakan salah satu tahapan pengujian untuk mendapatkan nilai dari kadar organik suatu tanah. Hasil analisis sampel tanah dilakukan di laboratorium menunjukan bahwa kandungan kadar abu dengan kisaran 5,25-72,06 semakin tinggi kadar abu pada tanah gambut maka kadar mineral juga semakin tinggi (Noor, 2001). Selain sebagai penentu tingginya kedalaman dan kematangan gambut. Tingkat kadar abu mempunyai hubungan dengan tingkat kematangan gambut.

8. $\mathrm{C} / \mathrm{N}$ kedalaman $0-20 \mathrm{~cm}$

$\mathrm{C} / \mathrm{N}$ berguna sebagai penanda kemudahan perombakan bahan organik dan kegiatan jasad renik tanah. Akan tetapi apabila $\mathrm{C} / \mathrm{N}$ terlalu besar, berarti ketersediaan $\mathrm{C}$ sebagai sumber energy berlebihan menurut bandingnya dengan ketersediaan $\mathrm{N}$ bagi pembentuk protein mikrobia, kegiatan jasad renik akan terhambat. Maka $\mathrm{C} / \mathrm{N}$ di atas kira-kira 25:1 membuat laju mineralisasi bahan organik rendah, apabila tidak ada sumber arternatif $\mathrm{N}$ dalam tanah yang dapat dimetabolisasikan oleh mikroorganisme (ammonium dan nitrat). Pada C/N di bawah 20:1 banyak $\mathrm{N}$ yang dimineralisasikan. Hasil analisis sampel tanah dilakukan di laboratorium menunjukan bahwa kandungan $\mathrm{C} / \mathrm{N}$ dengan kisaran 11,8-28,15. Hal ini menggambarkan bahwa kecepatan dekomposisi gambut justru relatif lebih cepat terjadi pada lahan gambut yang tidak terbakar dan lahan berhutan. Ini membuktikan bahwa kebakaran lahan di lokasi ini berpengaruh pada lahan tanah gambut karena karena pada lahan yang terbakar nilai $\mathrm{C} / \mathrm{N}$-nya lebih rendah dari gambut yang tidak terbakar.

$\mathrm{C} / \mathrm{N}$ berkisar $31-49$, bila nilai $\mathrm{C} / \mathrm{N}$ rasio besar dari 30 akan terjadi immobilisasi $\mathrm{N}$ oleh mikrobiologi tanah untuk memenuhi kebutuhan metabolismenya. Sedangkan bila rasio $\mathrm{C} / \mathrm{N}$ anatara 20-30 dapat terjadi immobilisasi maupun pembebasan $\mathrm{N}$ ke dalam tanah gambut. Dengan rasio $\mathrm{C} / \mathrm{N}$ 
tanah gambut di atas 30 maka $\mathrm{N}$ pada tanah gambut ini sukar tersedia bagi tanaman (Barchia, 2006). Hasil analisis sampel tanah dilakukan di laboratorium menunjukan bahwa kandungan $\mathrm{C} / \mathrm{N}$ dengan kisaran 11,83-28,62 meskipun kandungan $\mathrm{N}$-total gambut terkatagori tinggi, namun unsur hara $\mathrm{N}$ relative kurang tersedia bagi tanaman karena $\mathrm{N}$ dalam bentuk N-organik dan pada tingkatan $\mathrm{C} / \mathrm{N}$ rasio yang tinggi tersebut terjadi proses immobilisasi N mikrobiologi tanah (Barchia, 2006).

\section{Kesimpulan}

1. Sifat Fisik Tanah Gambut

- Suhu tanah terbakar yaitu $29^{\circ} \mathrm{C}$ $32^{\circ} \mathrm{C}$ dan tidak terbakar yaitu $29^{\circ} \mathrm{C}-31^{\circ} \mathrm{C}$ ini menunjukan bahwa di lokasi terbakar dan tidak terbakar rerata hampir sama.

- Nilai kelembaban tanah di lokasi terbakar reratanya $67,06 \%$ relatif berbeda di lokasi tidak terbakar $82,84 \%$.

- Suhu udara relatif berbeda diantara di lokasi terbakar reratanya $62,76^{\circ} \mathrm{F}$ sedangkan di lokasi tidak terbakar $68,42^{\circ} \mathrm{F}$.

- Nilai kelembaban udara di lokasi terbakar reratanya 77,88 $\%$ sedangkan di lokasi tidak terbakar reratan 80,06\%.

2. Sifat Kimia Tanah Gambut

- pH tanah di lokasi terbakar kedalaman $\quad 0-20 \mathrm{~cm}$ sedikit lebih tinggi dari pada di lokasi tidak terbakar sedangkan di kedalaman 21-40 $\mathrm{cm}$ di lokasi tidak terbakar terindikasi hampir sama.

- C-organik, Kapasitas tukar kation, Nitrogen, dan $\mathrm{C} / \mathrm{N}$ kedalaman 0-20 cm di lokasi tidak terbakar sedikit lebih tinggi dari pada di lokasi terbakar sedangkan kedalaman 21-40 cm di lokasi tidak terbakar sedikit lebih tinggi dari pada di lokasi terbakar.

- Fosfor, Belerang, Kadar abu kedalaman 0-20 cm di lokasi terbakar sedikit lebih tinggi dari pada di lokasi tidak terbakar sedangkan kedalaman 21-40 cm lebih sedikit tinggi di lokasi tidak terbakar dari pada di lokasi terbakar.

- C/N di lokasi tidak terbakar kedalaman 0-20 cm sedikit lebih tinggi dari pada di lokasi terbakar sedangkan di kedalaman 21-40 cm di lokasi tidak terbakar sedikit lebih tinggi di lokasi terbakar.

\section{Saran}

Banyaknya unsur hara akibat kebakaran hutan tidak selalu mempengaruhi pertumbuhan pohon menjadi lebih baik meskipun haranya lebih tinggi tetapi bersifat sementara.

\section{DAFTAR PUSTAKA}

Andriesse JP. 1974. Tropical Peats in South East Asia. Dept. Of the Royal Trop. Inst. Comm. Amsterdam 63 p.

Arnold, James E. 1999. Soil Moisture. USA: GHCC, Inc.

Agus F, Hairiah K, Mulyani A. 2011. Petunjuk Teknis: Pengukuran 


\begin{abstract}
Cadangan Karbon Tanah Gambut. Balai Penelitian Tanah. Bogor 57 hal.
\end{abstract}

Abdul R, Fauzi. 2013. StudiDampak Kebakaran Lahan Gambut di Areal HGU PT. Gelora Sawita Makmur (PT. GSM) Kabupaten Nagan Raya Provinsi Aceh. Manajemen PT. GSM (tidak dipublikasi).

Brady NC. 1974. The Nature and Properties of Soils, $8^{\text {th }}$ Ed. MacMillan Pub.Co. Inc., New York.

Barchia MF. 2006. Gambut Agroekosistem dan Transformasi Karbon. UGM Press. Yogyakarta.

Ekinci H. 2006. Effect of Forest Fireon Some Physical, Chemical and Biological Properties of Soil in Canakkale, Turkey.International Journal of Agriculture an Biology 8 (1):102-106.

Fauzi Y. 2008. Kelapa Sawit: Budi Daya Pemanfaatan Hasil dan Limbah Analisis Usaha dan Pemanfataan.

Goenandi DH. 2006. Pupuk dan Teknologi Pemupukan berbasis Hayati dari Cawan Petri ke Lahan Petani. Edisi Pertama. Yayasan John Hi-Tech Idetama. Jakarta.

Jamulya, Suratman. 1993. Pengantar Geografis Tanah. Fakultas Geografis UGM: Yogyakarta.

Lutfiyana, Hudallah N, Suryanto A. 2017. Rancangan Alat Ukur Suhu
Tanah, Kelembaban Tanah, dan Resistansi. Semarang. Universitas Negara Semarang.

Mukhlis, Sarifuddin, Hanum H. 2011. Kimia Tanah: Teori dan Aplikasi. USU Press. Medan.

Noor M. 2001. Pertanian Lahan Gambut Potensi dan Kendala. Penerbit Kanisius.

Nugroho Y. 2009. Analisis Sifat FisikKimia Dan Kesuburan Tanah Pada Lokasi.

Setiawan HK. 1991. Akibat Pemamfataan atas Sifat-sifat Hidrologi Gambut Sehubung dengan Tingkat Perombakan. Tesis Sarjana Dep. Ilmu Tanah. Fakultas Pertanian. Universitas Gadjah Mada. Yogyakarta.

Usuga JCL, Toro JAR, Alzate MVR, de Jesus Lema Tapias A. 2010. Estimation of biomass and carbon stocks in plants, soil and forest floor in different tropical forest floor in different tropical forests. Forest Ecology and Management 260: 1906-1913.

Wahyunto, Ritung S, Suparto, Subagyo H, 2005. Sebaran Gambut dan Kandungan Karbon di Sumatera dan Kalimantan. Proyek Climate Change, Foresta, and Peatlanda in Indonesia. Wetlands International. Indonesia Programmed anWidlife Habitat Canada. Bogor. 